\title{
Optimization of conditions for the single step IMAC purification of miraculin from Synsepalum dulcificum
}

\begin{abstract}
In this study, the methods for extraction and purification of miraculin from Synsepalum dulcificum were investigated. For extraction, the effect of different extraction buffers (phosphate buffer saline, Tris- $\mathrm{HCl}$ and $\mathrm{NaCl}$ ) on the extraction efficiency of total protein was evaluated. Immobilized metal ion affinity chromatography (IMAC) with nickel-NTA was used for the purification of the extracted protein, where the influence of binding buffer $\mathrm{pH}$, crude extract $\mathrm{pH}$ and imidazole concentration in elution buffer upon the purification performance was explored. The total amount of protein extracted from miracle fruit was found to be 4 times higher using $0.5 \mathrm{M} \mathrm{NaCl}$ as compared to Tris- $\mathrm{HCl}$ and phosphate buffer saline. On the other hand, the use of Tris- $\mathrm{HCl}$ as binding buffer gave higher purification performance than sodium phosphate and citrate-phosphate buffers in IMAC system. The optimum purification condition of miraculin using IMAC was achieved with crude extract at $\mathrm{pH}$ 7, Tris- $\mathrm{HCl}$ binding buffer at $\mathrm{pH} 7$ and the use of $300 \mathrm{mM}$ imidazole as elution buffer, which gave the overall yield of $80.3 \%$ and purity of $97.5 \%$. IMAC with nickel-NTA was successfully used as a single step process for the purification of miraculin from crude extract of S. dulcificum.
\end{abstract}

Keyword: Synsepalum dulcificum; Miraculin; Nickel-NTA; Imidazole; Purification 